\title{
Update on the Development of Anti-Viral Agents Against Hepatitis C
}

\author{
Kristin L. MacArthur ${ }^{1}$, Robert Smolic ${ }^{2}$, Martina V. Smolic ${ }^{2}$, Catherine H. Wu ${ }^{3}$ and George Y. Wu ${ }^{3}$ \\ ${ }^{1}$ Department of Medicine, Beth Israel Deaconess Medical Center, Boston, MA02215; ${ }^{2}$ Faculty of Medicine, Osijek, Croatia; \\ ${ }^{3}$ Department of Medicine, Division of Gastroenterology-Hepatology, University of Connecticut Health Center,
} Farmington, CT, USA

\begin{abstract}
Hepatitis C virus (HCV) infects nearly 170 million people worldwide and causes chronic hepatitis, cirrhosis, and hepatocellular carcinoma. The search for a drug regimen that maximizes efficacy and minimizes side effects is quickly evolving. This review will discuss a wide range of drug targets currently in all phases of development for the treatment of $\mathrm{HCV}$. Direct data from agents in phase III/IV clinical trials will be presented, along with reported side-effect profiles. The mechanism of action of all treatments and resistance issues are highlighted. Special attention is given to available trial data supporting interferon-free treatment regimens. HCV has become an increasingly important public health concern, and it is important for physicians to stay up to date on the rapidly growing novel therapeutic options.

( $) 2013$ The Second Affiliated Hospital of Chongqing Medical University. Published by XIA \& HE Publishing Ltd. All rights reserved.

\section{Introduction}

Hepatitis C virus (HCV), a member of the Flaviviridae family, is a single-stranded enveloped RNA virus that infects approximately 170 million people worldwide. That number is increasing at a rate of approximately 3 to 4 million infections each year. In the USA, 3.2 million people $(1.8 \%$ of the population) are chronically infected with $\mathrm{HCV}$, and approximately 10,000 die annually as a result of this persistent infection. ${ }^{1} \mathrm{HCV}$ is an important public health burden, for which associated liver disease complications and deaths in the USA is currently estimated to peak between 2015 and $2030 .^{2}$ Chronic HCV infection is a leading cause
\end{abstract}

Keywords: HCV; Protease; Polymerase; Triple therapy; Drug.

Abbreviations: aa, amino acid; $A E$, adverse event; ALT, alanine aminotransferase; DAA, direct-acting anti-viral agent; ER, endoplasmic reticulum; eRVR, extended rapid virologic response; FUSE, far upstream element; HCV, hepatitis $C$ virus; IFN, interferon; IRES, internal ribosome entry site; NS, non-structural; PegIFN, pegylated interferon; PI, protease inhibitor; PTB protein, polypyrimidine tract binding protein; RBV, ribavirin; RVR, rapid virologic response; SCARB1, scavenger receptor class B Type 1 binding lectins; STAT-C, specifically targeted anti-viral therapy for hepatitis C; SVR, sustained virologic response; UTR, untranslated region.

Received: 12 March 2013; Revised: 14 May 2013; Accepted: 14 May 2013 DOI of original article: http://dx.doi.org/10.14218/JCTH.2013.007XX

Correspondence to: George Y. Wu, Department of Medicine, Division of Gastroenterology-Hepatology, University of Connecticut Health Center, Farmington, CT, USA 06030, E-mail: wu@nso.uchc.edu of chronic hepatitis, liver cirrhosis, and hepatocellular carcinoma. $^{3-5}$

There are 6 major genotypes and over 50 subtypes of $\mathrm{HCV}$ with considerable heterogeneity between them. The HCV genome contains approximately 10,000 nucleotides, which are translated into a single large polyprotein. ${ }^{6,7}$ Replication of the virus is performed by an HCV-encoded RNA-dependent polymerase, which lacks proofreading capability. As a result, the virus has an extremely high mutation rate, and thus there is a high prevalence of viral variants in infected individuals, and ultimately a high frequency of chronicity of infection. ${ }^{8}$ Historically, interferon alone, followed by a combination of interferon and ribavirin (RBV), and pegylated interferon $\alpha$ (PegIFN) in combination with RBV have been used to treat HCV infection. Unfortunately, for patients with genotype 1 , the most prevalent genotype in the USA, Europe, Japan and China, treatment with PegIFN/RBV is successful in achieving a sustained virologic response (SVR) in less than $50 \%$ of cases even with a prolonged duration (48-72 weeks) of treatment. ${ }^{9,10}$ Furthermore, this dual therapy is associated with marked adverse event $(\mathrm{AE}),{ }^{11,12}$ leading to discontinuation of the therapy. ${ }^{13}$ Because of these drawbacks, there has been a strong impetus to develop alternative novel therapeutic options.

Most recently, two protease inhibitors (PIs), telaprevir (Incivek; Vertex Pharmaceuticals Inc., Cambridge, MA, USA) and boceprevir (Victrelis; Schering-Merck, Whitehouse Station, NJ, USA) have been approved by the FDA in the USA, and have become the new standard of care for the treatment of $\mathrm{HCV}^{14-16}$ However, although the new agents greatly enhance the rates of SVR, the benefits have come at a price that includes significant side effects and drug-drug interactions. Therefore, there remains great interest in the development of superior agents for HCV therapy, which are targeted to unique aspects of viral replication in order to enhance specificity and decrease the likelihood of development of side effects.

\section{Virus-specific targets}

The HCV life cycle offers a number of possible targets for novel therapies. The HCV genome consists of a $9.6 \mathrm{~kb}$ uncapped linear single-stranded RNA with positive polarity. ${ }^{17}$ It contains $5^{\prime}$ - and $3^{\prime}$-untranslated regions (UTRs) including control elements required for translation and replication. The UTRs flank an uninterrupted open reading frame encoding a single polyprotein of 3,010 amino acids, which is processed into structural (C, E1, E2, and p7) and non-structural (NS2, 
NS3, NS4A, NS4B, NS5A, and NS5B) subunits. The NS proteins, excluding NS2, are necessary and sufficient for RNA replication in cell culture. ${ }^{18}$ NS5B is an RNA dependentRNA polymerase, and NS3 functions as both an RNA helicase and a serine protease. NS4A has a transmembrane domain in its N-terminal part anchoring NS3 and NS3/4A in the endoplasmic reticulum (ER) membrane. ${ }^{19}$ NS4A thus acts as a cofactor for the NS3 protease. It also interacts with NS5A by regulating its phosphorylation. The NS3-4A complex is responsible for the production of mature viral proteins by cleaving the polyprotein downstream of NS3/NS4A, NS4A/ NS4B, NS4B/NS5A, and NS5A/NS5B. NS4B induces an ERderived membranous web, the likely site of HCV replication. ${ }^{20}$

All $10 \mathrm{HCV}$ proteins have been studied as potential antiviral targets. Drug discovery has mainly focused on the development of inhibitors of the NS proteins, the NS3-4A protease, and the NS5B RNA-dependent RNA polymerase. ${ }^{21,22}$ The HCV NS3-4A is a non-covalent complex comprised of NS3 and the cofactor NS4A. NS3 is a multifunctional protein with a serine protease domain located in the $\mathrm{N}$-terminal one-third (amino acid [aa] 1-180), and an NTPase/RNA helicase domain in the C-terminal two-thirds (aa 181-631). Both enzyme activities have been wellcharacterized, and high-resolution structures have been elucidated. ${ }^{23}$ The NS3 serine protease domain adopts a chymotrypsin-like fold with two $\beta$-barrel sub-domains. The structure is stabilized by a $\mathrm{Zn}^{2+}$ ion that is coordinated by Cys 97, Cys 99, Cys 145, and His 149. This $\mathrm{Zn}^{2+}$ binding site also plays an important role in the processing of the NS2/NS3 site by the NS2 protease. ${ }^{24}$ The catalytic triad of the NS3-4A protease is formed by His 57, Asp 81 , and Ser 139. The central portion of NS4A (aa 21-32) is required for proper folding of NS3 through the formation of a $\beta$-strand incorporated into the $\mathrm{N}$-terminal $\beta$-barrel of NS3. The $\mathrm{N}$-terminal hydrophobic portion of NS4A (aa 1-21) forms a transmembrane $\alpha$-helix required for the integral membrane association of the NS3-4A complex, ${ }^{25}$ while the C-terminal acidic portion (aa 40-54) has been shown to interact with other replicase components to contribute to HCV RNA replication and virus particle assembly. ${ }^{26,27}$

Because of the critical role of the NS3/4A protease in cleaving the HCV polyprotein into constituent functional components, and the lack of an analogous mechanism in mammalian cells, much research has and is being devoted to this potential target. Consequently, agents in the class are currently the most advanced in clinical development. Recently completed phase 3 studies on the NS3/4A PIs, telaprevir and boceprevir, in combination with PegIFN/RBV, yielded SVR rates in the range of $66-75 \%$ in the treatment of naive patients with HCV genotype 1 infection, and $59-66 \%$ in the treatment of patients with HCV genotype 1 infection who had relapsed on PegIFN/RBV treatment. Studies on the next generation of PIs are already underway (see below for details).

Another potential target of great interest is the NS5B RNA-dependent RNA polymerase. The enzyme has a classic "fingers, palm, and thumb" structure, ${ }^{28-30}$ in which interactions between the fingers and thumb sub-domains result in a completely encircled catalytic site that ensures synthesis of positive- and negative-strand HCV RNA. ${ }^{30}$ This polymerase is considered a primary target for directly targeted therapy partly because of the success of the anti-retroviral therapies targeting HIV-1 protease and polymerase, and the lack of an analogous replication mechanism in mammals. Extensive structural and biochemical characterization of the enzymes has provided the basis for efficient drug design.

The function of NS5A, a NS protein without enzymatic activity in the HCV life cycle, remains unknown. However, NS5A appears to be a modulator of critical viral functions, including facilitation of viral replication, virus assembly, and regulation of anti-viral interferon response. NS5A is a multifunctional protein that is expressed in basally phosphorylated ( $p 56)$ and hyperphosphorylated ( $p 58$ ) forms. Both phosphoproteins, p56 and p58, are phosphorylated at serine residues after the mature protein is released from the polyprotein. ${ }^{31}$ Other studies have shown that HCV NS5A interacts with the proteins of oncogene and IFN signaling pathways, ${ }^{32-35}$ and recently it was shown that HCV NS5A downregulates toll-like receptor (TLR)4-related signaling pathways and blocks lipopolysaccharide (LPS)-induced apoptosis in human hepatocytes, suggesting that it plays an additional important role in the maintenance of chronic infection and regulation of inflammation. ${ }^{36}$ Recent data indicate that NS5A could be a valid target for anti-viral agents.

The internal ribosome entry site (IRES) of HCV serves as a direct regulator for assembly of initiation of translation complexes on viral mRNA. ${ }^{37,38}$ The $5^{\prime}$-untranslated region ( $5^{\prime}$-UTR and the $5^{\prime}$-portion of the core-coding region of HCV RNA contains an IRES element. ${ }^{39}$ The 40 S ribosomal subunit binds to the HCV IRES in the vicinity of the initiation codon to yield the 48S complex, and does so without the assistance of canonical or non-canonical initiation factors. ${ }^{40,41}$ The bottom half of stem-loop III, including the pseudoknot structure, and the region around the initiation codon, are necessary and sufficient for binding of the $40 \mathrm{~S}$ ribosomal subunit. ${ }^{41}$ However, the $40 \mathrm{~S}$ ribosomal subunit bound to the HCV IRES is not competent for translation initiation. Canonical translation factors are also required for active translation. Because this mechanism is distinct from those observed in prototypical eukaryotic translation machineries, 37,38,42 inhibition of viral IRES could provide a virus-specific target for antiviral compounds.

\section{Host-specific targets}

The HCV life cycle depends on a multitude of host factors that contribute to many of the inter-individual differences seen in the susceptibility to infection, and to the course of the disease. ${ }^{43}$ Therefore, efforts have recently been directed toward identifying these host factors and blocking their access to the virus.

Because host factors are essential for efficient viral replication, they are of increasing interest as drug targets for antiviral treatment. Theoretical advantages include the likelihood of lower drug resistance, and broader activity against multiple HCV genotypes in the case of host-specific targets. However, polymorphisms in host factors and aberrant expression levels between individuals might be problematic for this antiviral approach. In recent years, novel tools such as high-throughput assays have been developed to screen for the relevant host factors in viral diseases. ${ }^{44,45}$ Several host-cell proteins, including the polypyrimidine tract binding protein (PTB), La autoantigen, ${ }^{46-48}$ RNA helicase A, nuclear factors NF90, NF110, and NF45, ${ }^{49}$ heterogeneous nuclear ribonucleoproteins (hnRNPs), ${ }^{50-52}$ and far upstream element (FUSE) binding protein ${ }^{53}$ have been reported to interact with the $5^{\prime}-$ and $3^{\prime}$-UTR regions. ${ }^{52}$ 
MacArthur K.L. et al: Review of anti-HCV drugs currently in development

The domains of the PTB protein have distinct RNA structural preferences: the $\mathrm{N}$-terminal RRMs preferentially bind to short $(\mathrm{U} / \mathrm{C})$ tracts displayed in loops, while the RRM3-RRM4 complex preferentially binds to longer flexible RNA sequences. Because it can bind to short and long polypyrimidine tracts, structured or single-stranded, PTB takes on the role of a versatile adaptor protein that facilitates formation of RNA-protein regulatory complexes, and represents an interesting antiviral target. ${ }^{54}$

It has been reported that various host factors are associated with HCV infection; however, only a few proteins have been functionally shown regulate HCV replication. ${ }^{55}$ Translation of HCV is initiated by an IRES that occupies most of the 5'-untranslated RNA. ${ }^{39}$ Many translation initiation factors, such as La protein, ${ }^{47}$ PTB, ${ }^{56}$ and eukaryotic initiation factor 3, interact with the HCV IRES, and might regulate HCV translation. It has been shown previously that HCV IRES activity is highly dependent on these initiation factors, and is correlated with the expression of La protein. ${ }^{57,58}$ The functional relevance of these translation initiation factors on HCV replication have been evaluated. ${ }^{57}$ Expression of La protein is induced by HCV infection, and this induces La proteinactivated telomerase activity in a human hepatoma cell line. Because La protein is essentially involved in HCV IRES activity, its production is induced by HCV itself. Because it stimulates telomerase activity, La might be a good potential therapeutic target. ${ }^{57}$

Inhibition of viral entry into HCV-permissive cells could provide an efficient mechanism for reduction or elimination of productive infection. Specific factors necessary for virus/ host-cell fusion are incompletely understood. Studies have defined surface receptor CD81 and scavenger receptor class B Type 1 binding lectins (SCARB1), together with claudin 1 protein, as necessary factors for HCV fusion and entry. ${ }^{59-62}$ Very recently, receptor tyrosine kinases have also been identified as HCV entry cofactors. ${ }^{63}$ These reports provide the foundation for design of inhibitors targeting one or more essential steps of HCV entry into host cells. Lupberger and colleagues showed that blocking receptor kinase activity by inhibitors broadly impaired infection by all major HCV genotypes, by viral escape variants in cell culture, and in a human liver chimeric mouse model in vivo. ${ }^{63}$

\section{Anti-HCV agents in development}

As discussed above, research on the virology of HCV has identified several targets for potential novel therapeutics. Unlike IFN $-\alpha$ and RBV, STAT-C (specifically targeted antiviral therapy for hepatitis C) agents are designed to target certain viral proteins or their functional epitopes. STAT-C has the theoretical potential to be effective in a greater proportion of patients, and result in fewer AEs than non-STAT-C agents. Many of these agents are in the preclinical developmental stage, and several are in clinical development. However, initial trials using some of these inhibitors alone have raised concerns about their tolerability and the development of viral resistance. A number of specifically targeted therapies are also now being tested in combination with PegIFN, with or without RBV. Viral components and proteins represent the most obvious target of antiviral treatment, but direct-acting antiviral therapies, in general, could be limited by the appearance of resistant viral variants. In addition to STAT-C, various host-targeted drugs are under investigation, includ- ing cyclophilin inhibitors, nitazoxanide, anti-steatosis drugs, immune modulators, and new IFN formulations.

\section{Viral entry inhibitors}

Although the mechanism of $\mathrm{HCV}$ internalization is still incompletely understood, the identification of required entry factors and development of neutralizing antibodies against the virus ${ }^{64-67}$ has permitted the discovery of a number of novel HCV entry inhibitors that may prove to be effective clinically. HCV entry into permissive cells is a complex event involving viral envelope glycoproteins as well as several cellular attachment and entry factors ${ }^{68}$ in the early process of attachment, followed by endocytosis and low pH-dependent fusion with endosomes. Attachment of the virus to the target cell is mediated through binding of HCV envelope glycoproteins E1 and E2 to glycosaminoglycans. ${ }^{69}$ Despite extensive research, many details about the structure and function of HCV glycoproteins E1 and E2 are not fully understood, and their crystal structure remains to be determined. HCV is internalized in a clathrin-dependent endocytic process requiring $\mathrm{CD} 81,{ }^{70}$ scavenger receptor type $\mathrm{B}$ class I (SR-BI) ${ }^{71}$ claudin-1 (CLDN1), ${ }^{72}$ and occludin (OCLN). ${ }^{73}$

The development of $\mathrm{HCV}$ infection models ${ }^{74-76}$ that reproduce the entire lifecycle of $\mathrm{HCV}$ in vitro has created the opportunity to discover novel antiviral compounds that could target every step in the viral life cycle. Therefore, the platform to recapitulate HCV particle adsorption, internalization, and viral envelope-mediated fusion has been established, and the impact of antiviral compounds on viral entry can now be evaluated.

Recently, using this system, compounds that have been clinically tested for a wide variety of indications were evaluated for their ability to inhibit HCV infection in vitro. ${ }^{77}$ Several compounds displayed antiviral activity in the absence of cytotoxicity at low micromolar and sub-micromolar concentrations. Many of the candidates were lysosomotropic compounds that inhibited HCV entry with various degrees of efficacy against genotype $1 \mathrm{a}(\mathrm{H} 77)$ and genotype $2 \mathrm{a}(\mathrm{JFH}-1)$ envelope glycoproteins. ${ }^{77}$ Indeed, the acid-activated proton pump $\mathrm{H}^{+} / \mathrm{K}^{+}$-ATPase inhibitor, rabeprazole, was shown to be inhibitory to HCV, although the mechanism by which this occurred was not identified. However, the discovery of compounds that target currently unapproachable aspects of $\mathrm{HCV}$ infection provides the opportunity to study events in the viral lifecycle that might otherwise remain elusive. ${ }^{77}$

Because receptors on the host-cell membrane are known to play a crucial role in viral entry and fusion, the attachment and entry stages present attractive targets for antibodies that can attack the virus at these stages. Various clinical and preclinical studies have investigated molecules that prevent the attachment of viral particles to receptor molecules, or inhibit entry of the virus by attaching to viral surface structures and neutralizing them, or compete with the virus at the receptor level.

Several entry inhibitors are in preclinical development, including SP-30 (Samaritan Pharmaceuticals, Las Vegas, NV, USA), and REP 9C (REPLICor; Laval, QC, Canada). In addition, several entry inhibitors are already in clinical trials including the human HCV immune globulin (HCIg: Civacir, Biotest Pharmaceuticals, Boca Raton, FL, USA) ${ }^{78}$ and 6 h4 SR-B1 inhibitor ITX5061 (iTherX Pharmaceuticals, San Diego, CA, USA)..$^{79}$ 
Chronic HCV is the most common indication for liver transplantation, and almost all transplanted livers are reinfected immediately after liver transplantation. Progressive graft injury occurs in most recipients, with $20 \%$ of patients dying or requiring a second transplant within 5 years of liver transplantation. ${ }^{81}$ For these patients, the use of IFN-based therapies to prevent re-infection of the transplanted liver has yielded poor response rates, accompanied by a high risk of treatment-limiting toxicity. ${ }^{82-84}$ Passive immunotherapy using monoclonal antibodies has resulted in promising results in chimpanzees; 85,86 however, satisfactory therapy for the treatment or prevention of recurrent HCV in liver transplant recipients remains elusive. $\mathrm{HCV}^{\mathrm{XTL}} 68$ is a fully human monoclonal antibody that binds to the E2 envelope protein of $\mathrm{HCV}$, which was generated by immortalizing peripheral blood mononuclear cells obtained from donors who tested positive for HCV. HCV-Ab ${ }^{\mathrm{XTL}} 68$ is of the IgG1 isotype with $\mathrm{V} / \mathrm{H}$ sub-groups $\mathrm{V}_{\mathrm{H} 3} / \mathrm{V}_{\mathrm{K}}$ and $\mathrm{V}_{\mathrm{H} 1} / \mathrm{V}_{\mathrm{k}}$ respectively. ${ }^{80}$ Four amino acids at the C-terminal end of the hypervariable region (HVR)1, and a further unknown number of E2 amino acids specify the epitope recognized by HCV-Ab ${ }^{\times T L} 68$. The epitope is conformational, and is relatively well conserved across HCV genotypes. In a phase 2 , placebo-controlled trial, the safety and efficacy of $\mathrm{HCV}-A b^{\times T L} 68$ for the prevention of $\mathrm{HCV}$ recurrence in patients undergoing liver transplantation has been examined. ${ }^{87}$ Median serum concentrations of HCV RNA dropped below baseline in all groups immediately after transplantation. On day 2 , the median change from baseline in HCV RNA was a maximum of $-2.4 \log _{10}$ compared with $-1.5 \log _{10}$ in the placebo group. However, that difference was lost after day 7 when the dosing frequency was reduced. The overall incidence of non-fatal serious adverse events (AEs) was higher with placebo $(60 \%)$ vs. all active treatments combined $(42 \%)$. $^{87}$

Targeting HCV entry factors using small molecules or antibodies may constitute a new approach to prevent and treat HCV infection with an emphasis on prevention of de novo infection of uninfected hepatocytes in the graft tissue by HCV from extrahepatic reservoirs by establishment of a neutralizing environment during the anhepatic phase.

\section{Inhibitors of viral protein synthesis and processing}

As discussed above, two NS3/4a PIs, telaprevir (TVR; VX950; Vertex) ${ }^{88,89}$ and boceprevir (BVR; SCH503034; Schering-Merck), ${ }^{90}$ have recently been approved by the FDA. Telaprevir, a linear peptidomimetic HCV NS3/4A serine PI, was associated with substantial improvements in response rates in phase 2 studies when it was combined with PegIFN/RBV. ${ }^{88,89,91}$ Moreover, high rates of early viral suppression and low rates of relapse after cessation of telaprevir therapy suggested that therapy could potentially be shortened to 24 weeks for patients in whom HCV RNA is undetectable at week 4 of treatment. ${ }^{88,89,91}$ A phase 3 study was conducted to evaluate the efficacy and safety of telaprevir-based therapy administered in a regimen that was guided by patient response (response-guided therapy) for patients who had received no previous treatment for HCV infection. ${ }^{92}$

Telaprevir-containing regimens, compared to PegIFN/RBV alone, were associated with a significant increase in the rates of SVR, both overall and in all the sub-groups of patients that were analyzed. The majority of patients who were treated with telaprevir had undetectable HCV RNA at weeks 4 and 12, and received only 24 weeks of total therapy. ${ }^{92}$ As suggested in phase 2 studies, telaprevir, compared with PegIFN/RBV alone, was also associated with a higher incidence of AEs such as rash, gastrointestinal disorders, and anemia. ${ }^{88,89,91}$ However, in phase 3 studies, rashes resolved with the discontinuation of telaprevir; $6 \%$ of patients discontinued telaprevir, and only 0.5 to $1.4 \%$ discontinued all therapy due to rash. The implementation of managed, sequential discontinuation of medications for severe rash may have led to lower rates of overall discontinuation of treatment in this study. ${ }^{92}$

The results of these phase 3 studies represent important advances in the treatment of patients with HCV genotype 1 infection, with significant improvement in the rates of SVR with telaprevir-based therapy. The capacity for responseguided therapy to shorten the duration of exposure to PegIFN/RBV for patients who had a rapid response ${ }^{92}$ is summarized below.

Approximately $60 \%$ of patients with HCV genotype 1 patients did not achieve SVR with 48 weeks of PegIFN $\alpha-2 a$ / RBV. ${ }^{89}$ These patients were divided into three categories: 1 ) no response to therapy (i.e. a reduction of $<2 \log _{10}$ in HCV RNA levels after 12 weeks of therapy); 2) partial response (a reduction of at least a $2 \log _{10}$ in a HCV RNA during therapy); and 3 ) relapse (undetectable serum HCV RNA at the end of treatment, but had subsequent reappearance of virus).

ILLUMINATE was a randomized, open-label trial conducted in treatment-naive subjects. The study was designed to compare SVR rates in subjects achieving extended rapid virologic response (eRVR), who were treated with for 12 weeks in combination with PegIFN/RBV for either 24 weeks (telaprevir12/PegIFN/RBV 24 regimen) or 48 weeks (telaprevir12/PegIFN/RBV 48 regimen). The SVR rate for all subjects enrolled in the trial was $74 \%$. A total of $352(65 \%)$ subjects achieved eRVR, and of those, 322 (60\%) were randomized to 24 weeks (telaprevir12/PegIFN/RBV 24, $\mathrm{n}=162$ ) or 48 weeks (telaprevir12/PegIFN/RBV $48, \mathrm{n}=160$ ) of treatment. The SVR rates were similar at 92\% (telaprevir12/PegIFN/RBV 24) and $90 \%$ (telaprevir12/PegIFN/RBV 48), respectively.

REALIZE was a randomized, double-blind, placebocontrolled, trial conducted in subjects who did not achieve SVR with prior treatment with PegIFN-2a/RBV or PegIFN $\alpha-2 b /$ RBV. The study enrolled prior relapsers (subjects with HCV RNA undetectable at end of treatment with a PegIFN-based regimen, but HCV RNA detectable within 24 weeks of treatment follow-up) and prior non-responders (subjects who did not have undetectable HCV RNA levels during or at the end of a prior course of at least 12 weeks of treatment). The non-responder population included 2 sub-groups: 1) prior partial responders $\left(\geqslant 2 \log _{10}\right.$ reduction in HCV RNA at week 12, but did not achieve undetectable HCV RNA at the end of treatment with PegIFN and 2) prior null responders (less than $<2 \log _{10}$ reduction in HCV RNA at week 12 of prior treatment with PegIFN/RBV). The SVRs for telaprevir12/ PegIFN/RBV 48 week-treated, prior relapsers, prior partial responders, and prior null responders were $86 \%, 59 \%$, and $32 \%$ for the telaprevir-treated group, respectively, and, $22 \%$, $15 \%$, and $5 \%$ for the PegIFN/RBV controls, respectively.

The most common AEs reported were rash (56\%), fatigue $(56 \%)$, pruritus $(47 \%)$, headache, nausea, dysgeusia, and anemia. Dysgeusia occurred three times as often in telaprevir recipients than in controls. Anemia was reported as an $\mathrm{AE}$ in 
MacArthur K.L. et al: Review of anti-HCV drugs currently in development

$36 \%$ in telaprevir-treated patients compared to $17 \%$ in PegIFN/RBV controls.

The ADVANCE trial was an international, randomized, phase 3, double- blind, placebo-controlled study that evaluated treatment-naïve patients with genotype $1 \mathrm{HCV}$. Subjects, 1088 in total, were divided into three groups to determine the optimal duration and combinations of treatment with telaprevir and PegIFN $\alpha-2 a / R B V$ with SVR as the primary endpoint. Groups 1 and 2 received telaprevir and PegIFN $\alpha-2 a / R B V$ for either 8 or 12 weeks, followed by PegIFN $\alpha-2 a / R B V$ alone for a duration of up to 36 weeks, as determined by response in terms of HCV RNA detectability at 4 and 12 weeks of treatment. The control group received PegIFN $\alpha-2 a / R B V$ and placebo for 12 weeks, followed by PegIFN $\alpha-2 a / R B V$ alone for 36 weeks. SVRs were $75 \%$ in group $1,69 \%$ in group 2, and $44 \%$ in the control group, demonstrating statistically significant improvement in treatment outcomes in genotype 1 patients receiving telaprevir in addition to PegIFN $\alpha-2 a / R B V$ therapy compared to with PegIFN $\alpha-2 a / R B V$ therapy alone. Moreover, $58 \%$ of patients treated with telaprevir were able to receive only 24 weeks of therapy based on undetectable viral loads at 4 and 12 weeks. AEs effects included gastrointestinal side effects, anemia, and rash.

Boceprevir is a linear peptidomimetic ketoamide serine PI that binds reversibly to the HCV NS3 active site. ${ }^{93}$ In order to minimize the emergence of viral resistance, boceprevir, like other PIs, must be given in combination with PegIFN/RBV. As an additional strategy to prevent resistance, a 4 week lead-in period of PegIFN/RBV prior to initiation of boceprevir was adopted.

SPRINT-2 was a randomized, double-blind, placebocontrolled study comparing two therapeutic regimens of boceprevir $800 \mathrm{mg}$ orally three times daily in combination with PegIFN/RBV compared with to PegIFN/RBV alone in adult subjects who had HCV genotype 1 infection not previously treated with IFN- $\alpha$ therapy. Subjects were randomized in a $1: 1: 1$ ratio within two separate cohorts (cohort 1 /non-Black and cohort 2/Black) and were stratified by HCV genotype (1a or $1 \mathrm{~b})$, and by HCV RNA viral load ( $\leqslant 400,000 \mathrm{IU} / \mathrm{mL}$ vs. $>400,000 \mathrm{IU} / \mathrm{mL}$ ) to one of the following three treatment arms:1) PegIFN/RBV for 48 weeks (PR48), PegIFN/RBV for 4 weeks followed by boceprevir $800 \mathrm{mg}$ three times daily plus PegIFN/RBV for 24 weeks. The subjects were then continued on different regimens based on treatment weeks 8 through 24. Boceprevir plus PegIFN/RBV SVR rates of $63-66 \%$ were significantly higher than the $38 \%$ treated with PegIFN/RBV alone. SVR rates for Black subjects in a predefined analysis who received the combination of boceprevir with PegIFN/RBV were from $42 \%$ to $53 \%$.

RESPOND-2 was a randomized, parallel-group, doubleblind study comparing two therapeutic regimens of boceprevir $800 \mathrm{mg}$ orally three times daily in combination with PegIFN/RBV compared with PegIFN/RBV alone in adult subjects with HCV genotype 1 infection with demonstrated IFN responsiveness (a previous decrease in HCV RNA viral load $\geqslant 2 \log _{10}$ by week 12 , but no SVR [partial responders] or 2) undetectable HCV RNA at end of prior treatment with a subsequent detectable HCV RNA in plasma [relapsers]). Subjects with $<2 \log _{10}$ decrease in HCV RNA by week 12 of previous treatment (prior null responders) were not eligible for enrollment in this trial. Subjects were randomized in a $1: 2: 2$ ratio, and stratified based on response to their previous qualifying regimen (relapsers vs. partial responders) and by
HCV subtype (1a vs. $1 \mathrm{~b}$ ) to one of the following treatment arms: 1) PegIFN/RBV for 48 weeks or 2) PegIFN/RBV for 4 weeks followed by boceprevir $800 \mathrm{mg}$ three times daily plus PegIFN/RBV for 32 weeks. The subjects were then continued on different treatment regimens based on treatment weeks 8 and 12 response-guided therapy. All subjects in this treatment arm were limited to 32 weeks of boceprevir. Subjects with undetectable HCV RNA at treatment week 8 (early responders) and treatment week 12 completed therapy at treatment week 36. Subjects who had detectable HCV RNA at treatment week 8 , but were subsequently undetectable at treatment week 12 (late responders) were changed in a blinded fashion to placebo at the treatment week 36 visit, and were continued on treatment with PegIFN/RBV for an additional 12 weeks, for a total treatment duration of 48 weeks or 3) PegIFN/RBV for 4 weeks followed by boceprevir plus PegIFN/RBV for 44 weeks.

The addition of boceprevir to the PegIFN/RBV therapy significantly increased the SVR rates compared with PegIFN/ RBV alone, $59 \%$ to $66 \%$ for the boceprevir-containing arms vs. $23 \%$ for the PegIFN/RBV controls treated for 48 weeks. The most common AEs reported were fatigue, headache, nausea, dysgeusia, and anemia. Dysgeusia occurred more than twice as often in boceprevir recipients than in controls. Anemia was reported as an $\mathrm{AE}$ in $49 \%$ of boceprevir recipients and $29 \%$ of PegIFN/RBV controls. ${ }^{92}$

Several second-generation PIs are in various stages of development: TMC-435 (Tibotec/Medevir/Johnson) and BI 201,335 (Boehringer-Ingelheim) have reached phase 3 clinical trials, and danoprevir (ITMN-191, RG7227; Roche), ABT-450 (Abbott/Enanta), vaniprevir (MK-7009; Merck), BMS-650,032 (Bristol-Myers Squibb), ACH-1625 (ACH0,141,625; Achillion) and GS-9256 (Gilead) ${ }^{94}$ have reached phase 2 clinical trials.

TMC435, a macrocyclic PI jointly developed by Medivir and Tibotec Pharmaceuticals, has been described as a potent and specific inhibitor of HCV replication. ${ }^{95}$ In a phase 1 clinical trial, TMC435 was shown to have potent antiviral activity with a median maximal reduction in plasma HCV RNA levels of $3.9 \log _{10} \mathrm{IU} / \mathrm{mL}$ without serious AEs, grade 3 reactions, or treatment-related discontinuations. Pharmacokinetics supported a substantial advantage of once-daily dosing. ${ }^{96}$ In a phase $2 b$ study assessing the optimal dose and duration as a once-daily antiviral regimen (PILLAR), all 386 patients received PegIFN/RBVfor 24 weeks, and were then randomized to add either $75 \mathrm{mg}$ or $150 \mathrm{mg}$ oral TMC435 once daily for 12 or 24 weeks. The fifth group received a combination of PegIFN/RBV for 48 weeks. All patients included in this study and assigned to a TMC-435 arm had a rapid and steep decline in HCV RNA during the first 4 weeks of treatment (RVR), which was maintained throughout the 12 week or 24 week dosing period. In contrast, the control group showed a much slower slope of decline, needing about 8 weeks to achieve a $4 \log _{10}$ decline, and the nadirs for this group never achieved the same degree of decline in HCV RNA as the TMC-435 groups. The proportion of patients with very low or undetectable HCV RNA $(<25 \mathrm{IU} / \mathrm{mL})$ at week 4 ranged from $88 \%$ to $96 \%$ in the TMC435 groups, compared with $16 \%$ in the control group. At week 12, the early virologic response (EVR) rate was $91 \%$ in those randomized to 12 weeks of TMC435 treatment, $97 \%$ in those randomized to 24 weeks of TMC 435 , and $69 \%$ in the controls. Viral breakthrough by week 24 occurred in $2.5-7.8 \%$ of the TMC435 groups, compared with $3.9 \%$ of the control group. 
ASPIRE (TMC435-C206; NCT00980330), a phase IIb, randomized, double-blind, placebo-controlled trial, investigated the efficacy, tolerability, safety, and pharmacokinetics of TMC435 as part of a treatment regimen including PegIFN/ RBV. HCV genotype 1 patients who had failed to respond to or had relapsed following at least one course of PegIFN/RBV therapy were enrolled. Phase III clinical trials are now underway in treatment-naïve patients and in patients who relapsed after previous treatment.

BI 201,335 is a linear second-generation PI with an optimized chemical structure believed to improve interactions with the NS3 substrate binding site. ${ }^{97}$ It features a C-terminal carboxylic acid, which is the same functional group found in natural cleavage products. Data from a phase Ib study (SOUND-C1) were presented in 2010.98 An IFN-free triple therapy consisting of BI 201,335 (PI) plus BI 207,127 (an NS5B polymerase inhibitor) and RBV was assessed for efficacy in the treatment of 32 treatment-naïve patients with HCV genotype 1 . Thirty-two treatment-naive patients with genotype $1 \mathrm{HCV}$ received BI 207,127 in either $400 \mathrm{mg}$ or $600 \mathrm{mg}$ doses 3 times a day, BI 201,335 120 mg once daily, and RBV (1000/1200 mg daily in 2 doses) for 28 days. All patients had rapid and sharp declines in HCV viral load during the first 2 days, followed by slower second-phase declines. In the lower and higher dose groups, $73 \%$ and $100 \%$ of patients, respectively, achieved RVR (HCV RNA less than the lower limit of quantification after 4 weeks of treatment). One patient experienced a viral breakthrough (increase by $>1$ $\log _{10}$ from nadir during treatment), and one other patient experienced a $0.7 \log _{10}$ increase in viral load. Both were in the lower dose group of BI 207127, and were patients with high baseline viral loads. On day 29, all patients were switched to treatment with BI 201335 and PegIFN/RBV for an additional 44 weeks as defined in the study protocol, and followed up to evaluate SVR. This work may be an important step toward a viable treatment option for the large number of patients with contraindications or intolerance to IFN. Recently, data about the safety and pharmacokinetics of BI 201335 in 43 treatment-naïve patients were published. Although the drug induced strong antiviral responses in most patients, with a viral load decline similar to other potent PIs in clinical development, a dose-dependent, but asymptomatic unconjugated hyperbilirubinemia was observed.

\section{Viral replication inhibitors}

Small molecule inhibitors of the NS5B polymerase have been identified, and fall into two general types: 1) nucleoside analogs that bind to the active site, and 2) allosteric nonnucleoside inhibitors (NNI) that bind sites at variable distances from the active site of the polymerase. Although the NS5B polymerase inhibitors have generally lagged behind the PIs in their clinical development, they are capable of substantial suppression of viremia. ${ }^{99}$

We have shown recently that single-stranded RNA structural analogs designed to mimic the shape of natural viral nucleic acids, without anti-sense capablity, can inhibit replication of HCV. ${ }^{100}$ Accumulating data continues to reveal that HCV RNA replication is a highly complex process, dependent on both viral and host proteins. Agents that block viral replication by inhibiting other HCV NS proteins or targeting host-cell proteins shown to be essential for viral replication, such asNS5A inhibitors (Bristol-Myers-Squibb), ${ }^{101}$ the NS4B inhibitor clemizole (EigerBioPharmaceuticals), ${ }^{102}$ HMG Co A reductase inhibitors, ${ }^{103}$ cyclophilin inhibitors [e.g. DeBIO025 (DebioPharm), ${ }^{104}$ SCY-635 (Scynexis) and NIM 811 (Novartis),${ }^{105,106}$ and the liver-specific microRNA miR-122 inhibitor LNA-anti-miR/SPC3649 (SantarisPharma) ${ }^{107,108}$ are all only in early (<phase II) stage development at present.

NS5A phosphorylation has been implicated in regulating multiple aspects of $\mathrm{HCV}$ replication. Qui et al. recently reported the identification of a class of compounds that potently inhibit HCV RNA replication by targeting NS5A. Although the precise mechanism of inhibition of these compounds is not well understood, one activity that has been described is the ability to inhibit hyperphosphorylation of NS5A. The NS5A inhibitor impaired hyperphosphorylation without affecting basal phosphorylation at the C-terminal region of NS5A. This inhibitory activity did not require NS5A domains II and III, and was distinct from that of a cellular kinase inhibitor that also blocked NS5A hyperphosphorylation, results that are consistent with action at an inhibitory binding site within the N-terminal region of NS5A. In addition, they observed that an NS5A inhibitor promoted the accumulation of an HCV polyprotein intermediate, suggesting that inhibition of binding to NS5A may occur prior to the completion of polyprotein processing. They also observed that NS5A p56 and p58 separated into different membrane fractions during discontinuous sucrose gradient centrifugation, consistent with the concept that NS5A phosphoforms perform distinct replication functions. The p58 localization pattern was disrupted by an NS5A inhibitor. Finally, the results suggest that NS5A inhibitors likely impact multiple aspects of HCV expression and regulation. ${ }^{109}$ Focusing on the critical importance of NS5A for HCV replication, BMS-790052 was identified as a potent and highly selective inhibitor of HCV based on inhibitor binding and mapping, inhibitor-induced resistance substitutions, and crystal structure modeling. In vitro data have shown that BMS-790052 inhibits HCV genotype 1 replicons with a median $50 \%$ effective concentration of $50 \mathrm{pmol} / \mathrm{L}$, while BMS-790052-resistant variants remain fully sensitive to IFN and small molecule inhibitors of HCV polymerase and protease. ${ }^{110}$ In clinical settings, BMS7590052 was the first NS5A replication complex inhibitor to demonstrate proof-of-concept with multiple doses. ${ }^{111}$ In a 14-day study of BMS-790052 at doses of $1,10,30,60$, or $100 \mathrm{mg}$ once daily or $30 \mathrm{mg}$ twice daily, BMS-790052 was well tolerated, had a pharmacokinetic (PK) profile supportive of once-daily dosing, and produced mean maximum declines in HCV RNA levels from 2.8 to $4.1 \log _{10} \mathrm{IU} / \mathrm{mL}$ in patients chronically infected with HCV genotypes $1 \mathrm{a}$ or $1 \mathrm{~b} .^{111}$ However, most patients experienced viral rebound on or before day 7 of treatment with BMS-790052 monotherapy. Viral rebound was associated with viral variants that had been previously implicated in the development of resistance in an in vitro replicon system.

RG7128 is a $3^{\prime}, 5^{\prime}$-di-isobutyric acid ester prodrug of the cytosine nucleoside analog $\beta$-D-2'-deoxy-2'-fluoro-2'-Cmethylcytidine, which in its triphosphate form, inhibits $\mathrm{HCV}$ NS5B RNA polymerase. Danoprevir (RG7227) is a macrocyclic inhibitor of the HCV NS3/4A protease. Both compounds have potent in vitro and in vivo activity against HCV. ${ }^{113-115}$ Recently, the safety, tolerability, and antiviral activity of an all-oral combination treatment with these two experimental anti-HCV drugs have been evaluated in patients with chronic $\mathrm{HCV}$ infection. ${ }^{98}$ Patients chronically infected with HCV genotype 1 received up to 13 days of oral combination treatment with RG7128 (500 mg or $1000 \mathrm{mg}$ twice daily) 
MacArthur K.L. et al: Review of anti-HCV drugs currently in development

Table 1. Trial status summary of hepatitis $C$ virus agents in clinical development (as of March 2013)

\begin{tabular}{|c|c|c|}
\hline Name & Company & Trial Status \\
\hline \multicolumn{3}{|l|}{ STAT-Cprotease inhibitors } \\
\hline ABT-450 & Abbott/Enanta & Phase II \\
\hline ACH-1625 (Sovaprevir) & Achillion & Phase II \\
\hline $\mathrm{ACH}-2684$ & Achillion & Phase I \\
\hline BI 201335 (Faldaprevir) & Boehringer-Ingelheim & Phase III \\
\hline BMS 650032 (Asunaprevir) & Bristol-Myers-Squibb & Phase II/III \\
\hline BMS 791325 & Bristol-Myers-Squibb & Phase II \\
\hline Boceprevir & Merck & Approved \\
\hline GS-9451 & Gilead & Phase II \\
\hline GS-9256 & Gilead & Phase II \\
\hline MK-5172 & Merck & Phase II \\
\hline MK7009 (Vaniprevir) & Merck & Phase II/III \\
\hline RG7227 (ITMN-191) (Danoprevir) & Genentech & Phase II \\
\hline Telaprevir & Vertex & Approved \\
\hline TMC435 (Simeprevir) & Tibotec/Janssen & Phase III \\
\hline \multicolumn{3}{|c|}{ Polymerase inhibitors, nucleoside type } \\
\hline ALS-2200 (VX-135) & Alios/Vertex & Phase II \\
\hline GS-7977 (PSI-7977) (Sofosbuvir) & Gilead & Phase III \\
\hline RG7128 (Mericitabine) & Genetech & Phase II \\
\hline VX-135 & Vertex & Phase II \\
\hline \multicolumn{3}{|c|}{ Polymerase inhibitors, non-nucleoside, allosteric } \\
\hline ABT-072 & Abbott/Enanta & Phase II \\
\hline ABT-333 & Abbott/Enanta & Phase II \\
\hline ANA598 (Setrobuvir) & Genentech & Phase II \\
\hline BI 207127 & Boehringer-Ingelheim & Phase II \\
\hline GS 9190 (Tegobuvir) & Gilead & Phase II \\
\hline PF-868554 (Filibuvir) & Pfizer & Phase II \\
\hline$V X-222$ & Vertex & Phase II \\
\hline \multicolumn{3}{|l|}{ NS5A inhibitors } \\
\hline ABT-267 & Abbott/Enanta & Phase II \\
\hline ACH-2928 & Achillion & Phase I \\
\hline $\mathrm{ACH}-3102$ & Achillion & Phase I \\
\hline AZD-7295 & Astra-Zeneca & Phase I \\
\hline BMS-790052 (Daclatasvir) & Bristol-Myers-Squibb & Phase III \\
\hline GS-5885 & Gilead & Phase II \\
\hline GSK2336805 & GlaxoSmithKline & Phase II \\
\hline IDX719 & Idenix & Phase II \\
\hline PPI-461 & Presidio & Phase I \\
\hline PPI-688 & Presidio & Phase I \\
\hline \multicolumn{3}{|l|}{ Interferons } \\
\hline Consensus (infergen) & InterMune/Three Rivers & Phase IV \\
\hline Omega interferon & Intarcia & Phase II \\
\hline Oral interferon & Amarillo Biosciences & Phase II \\
\hline$P E-\lambda$ interferon & Bristol-Myers-Squibb & Phase II \\
\hline \multicolumn{3}{|l|}{ Interferon enhancers } \\
\hline IET (EM7702) & Transition & Phase II \\
\hline TCM-700C & TCM Biotech & Phase II \\
\hline Vaccines & & \\
\hline
\end{tabular}


MacArthur K.L. et al: Review of anti-HCV drugs currently in development

Table 1. Continued

\begin{tabular}{|c|c|c|}
\hline Name & Company & Trial Status \\
\hline CHRONVAC-C & Inovio/Tripep & Phase II \\
\hline Civacir (HC-Ab) & Nabi Biopharmaceuticals & Phase II \\
\hline CT-101 & CureTech/Teva & Phase I \\
\hline GI-5005 (Tarmogen) & GlobeImmune & Phase II \\
\hline HCV/MF59 & Chiron/Novartis & Phase I \\
\hline IC41 & Intercell/Novartis & Phase II \\
\hline MBL-HCV1 & MassBiologics & Phase I \\
\hline TG4040 & Transgene & Phase II \\
\hline \multicolumn{3}{|l|}{ Immune modulators } \\
\hline CYT 107 & Cytheris & Phase I \\
\hline GS-6624 & Gilead & Phase II \\
\hline Infliximab, TNF-alpha-mAb & Schering-Plough-Merck & Phase III \\
\hline KRN7000, NKT-cell ligand & Kyowa Hakko Kirin & Phase II \\
\hline MDX-1106, PD-1 mAb & Bristol-Myers-Squibb & Phase I \\
\hline NOV-205 & NovelosTherapeutics & Phase I \\
\hline PEG-rIL-29 & ZymoGenetics & Phase II \\
\hline Thymosin alpha 1 & SciClone & Phase III \\
\hline \multicolumn{3}{|l|}{ Toll-like receptor ligands } \\
\hline ANA773 & Genentech & Phase I \\
\hline IMO-2125, TLR9 ligand & Idera & Phase I \\
\hline PF-04878691, TLR7 I & Pfizer & Phase I \\
\hline SD-101, TLR9 agonist & Dynavax & Phase I \\
\hline \multicolumn{3}{|l|}{ Host-specific agents } \\
\hline ALN-VSP & Alnylam & Phase I \\
\hline Alinia (nitazoxanide) & Romark Lab. & Phase II \\
\hline Celgosivir & BioWest & Phase II \\
\hline CF102, adenosine A3 receptor ligand & Can-FiteBioPharma & Phase I \\
\hline Cyclosporins & Novartis & Phase IV \\
\hline Fluvastatin (OUHSC) & Novartis & Phase II \\
\hline IDN-6556 & Pfizer & Phase II \\
\hline LGD-4665 & Ligand Pharmaceuticals & Phase II \\
\hline Miravirsen & Santaris & Phase II \\
\hline SCY-635 & Scynexis & Phase II \\
\hline Viramidine (taRBV) & Valeant & Phase III \\
\hline \multicolumn{3}{|l|}{ Entry inhibitors } \\
\hline ITX5061 & iTherX & Phase I \\
\hline \multicolumn{3}{|l|}{ NS4B RNA binding inhibitors } \\
\hline Clemizole & EigerBioPharmaceuticals & Phase I \\
\hline \multicolumn{3}{|l|}{ NS5B polymerase inhibitors } \\
\hline MBX-700 & Microbiotix/Merck & Phase I \\
\hline TMC 647055 & Janssen & Phase II \\
\hline \multicolumn{3}{|l|}{ Anti-liver cancer agents } \\
\hline Doxorubicin & Celsion & Phase III \\
\hline PI-88 & Progen Industries & Phase II \\
\hline PV-10 & Provectus & Phase I \\
\hline ZIO-101 & Ziopharm Oncology & Phase II \\
\hline 4SC-201(Resminostat) & 4SC AG & Phase II \\
\hline Halted trials & & \\
\hline
\end{tabular}

Continued 
MacArthur K.L. et al: Review of anti-HCV drugs currently in development

Table 1. Continued

\begin{tabular}{lll}
\hline Name & Company & Trial Status \\
\hline BMS-986094 (INX-189) & BMS & N/A \\
IDX 184 & Idenix & N/A \\
IDX 19368 & Idenix & N/A \\
IDX 320 & Idenix & N/A \\
PSI-938 & Pharmasset & N/A \\
MK-3281 & Nerck & N/A \\
DEB025 & Novartis & N \\
\hline
\end{tabular}

${ }^{*}$ Adapted from www.hcvadvocate.org.N/A, not applicable.

and danoprevir (100 $\mathrm{mg}$ or $200 \mathrm{mg}$ every $8 \mathrm{~h}$ or $600 \mathrm{mg}$ or $900 \mathrm{mg}$ twice daily) or placebo. In this study, 88 patients were randomly assigned to a study drug treatment regimen $(n=74)$ over seven treatment groups (73 received at least one dose of study drug) or to placebo $(n=14)$, all of whom received at least one dose. The median change in HCV RNA concentration from baseline to day 14 ranged from -3.7 to $-5.2 \log _{10} \mathrm{IU} / \mathrm{mL}$ in the cohorts that received 13 days of combination treatment. At the highest combination doses tested (1000 mg RG7128 and $900 \mathrm{mg}$ danoprevir twice daily), the median change in HCV RNA concentration from baseline to day 14 was $-5.1 \log _{10} \mathrm{IU} / \mathrm{mL}(-5.6$ to -4.7$)$ in treatment-naive patients and $-4.9 \log _{10} \mathrm{IU} / \mathrm{mL}$ in previous null responders ( -5.2 to -4.5$)$ compared with an increase of $0.1 \log _{10} \mathrm{IU} / \mathrm{mL}$ in the placebo group. The combination of RG7128 and danoprevir was well tolerated, with no treatment-related serious or severe AEs, no grade 3 or 4 changes in laboratory parameters, and no safety-related treatment discontinuations. This oral combination of a nucleoside analog polymerase inhibitor and PI holds promise as an IFN-free treatment for chronic HCV. ${ }^{98}$ RG7128 showed potent antiviral efficacy in patients infected with $\mathrm{HCV}$ genotypes 1 , 2, or 3, with mean viral load decreases of 2.7 and $5 \log _{10} \mathrm{IU} / \mathrm{mL}$, associated with $1500 \mathrm{mg}$ doses twice daily after monotherapy for 2 weeks, and with $1000 \mathrm{mg}$ and $1500 \mathrm{mg}$ doses twice daily after treatment in combination with the PegIFN/RBV for 4 weeks, respectively. Of the 32 patients treated with RG7128 monotherapy for 2 weeks, marginal viral load rebound was observed in 3 patients infected with HCV genotype 1 , whereas a partial response was observed in 2 patients. Of the 85 patients receiving RG7128 in combination with PegIFN/RBV, 1 patient infected with HCV genotype 1 experienced a viral rebound, and 2 patients infected with HCV genotype 3 experienced a transient rebound. Five patients infected with HCV genotype 1 had an HCV load of $>1000 \mathrm{IU} / \mathrm{mL}$ at the end of 4 weeks of treatment. No viral resistance was observed by NS5B sequencing and phenotypic studies. PSI-6130 resistance substitution S282T was required at levels of $\geqslant 90 \%$ within the quasispecies to confer low-level resistance. No evidence of S282T substitution was found by population or clonal sequence analyses. The requirement for a predominant S282T mutant quasispecies, its low replication capacity, and the low-level resistance it confers probably contribute to the lack of RG7128 resistance observed in HCV-infected patients. ${ }^{116}$

VX-222 is a novel non-nucleoside HCV polymerase inhibitor with potent in vitro activity. The safety, tolerability, pharmacokinetics, and antiviral activity of VX-222 were assessed in a phase Ib/IIa multicenter, randomized, doubleblinded, placebo-controlled, dose-ascending study. ${ }^{117}$ Treatment-naïve patients with HCV genotype 1 were randomized to receive $\mathrm{VX}-222$ at doses of $250 \mathrm{mg}$ twice daily, $500 \mathrm{mg}$ twice daily, $750 \mathrm{mg}$ twice daily, $1500 \mathrm{mg}$ once daily, or placebo for 3 days in a treatment: placebo ratio of $6: 2$ (eight patients/cohort). PegIFN $\alpha$-RBV (was offered to patients at the end of the study (day 4) for up to 48 weeks, as judged appropriate by the investigator. PegIFN/RBV treatment was discontinued in patients who had not experienced a decline of $\geqslant 2 \log _{10}$ in HCV RNA levels at week 12 . VX-222 plasma levels were assessed at multiple time points over $12 \mathrm{~h}$, on days 1 and 3 . There were 24 patients enrolled in the first three cohorts. VX-222 exposure was increased in a dose-related manner. The mean HCV RNA decline achieved on day 4 with placebo, $250 \mathrm{mg}, 500 \mathrm{mg}$, and $750 \mathrm{mg} \mathrm{VX}-222$ twice daily was $0.1 \log _{10}$ (range: 0.3 increase to 0.5 decline), $3.1 \log _{10}$ (range: 2.0 to 4.2 ), $3.4 \log _{10}$ (range: 3.2 to 3.6 ), and $3.2 \log _{10}$ (range: 2.3 to 3.8 ), respectively. All AEs reported were mild to moderate, and the most frequently reported AEs by patients that received either active drug or placebo were diarrhea $(25 \%)$, headache $(20 \%$, ) and nausea (12\%). No clinically relevant laboratory abnormalities were reported. VX-222 was well tolerated and a mean HCV RNA decline of $>3 \log _{10}$ at day 4 was observed in each cohort. These results support further evaluation of VX-222 in combination with PegIFN/RBV in the treatment of HCV. ${ }^{117}$

\section{Interferon-free based trials}

There is much anticipation for the development of IFN-free regimens for treatment of HCV. A 12 -week, phase $2 \mathrm{a}$, openlabel study was completed in January 2013 that evaluated ABT-450 (NS3 PI) with low-dose ritonavir and ABT-333 (nonnucleoside NS5B polymerase inhibitor) plus RBV in patients with HCV genotype 1 infection without cirrhosis. ${ }^{118}$ Subjects were separated into three groups; the first 2 two groups were treatment-naïve, and treatment differed only in dosing of ABT-450, whereas the third group consisted of subjects who had null or partial responses to previous therapy with PegIFN and RBV. The primary endpoint was extended rapid virologic response (eRVR which was defined by an undetectable HCV RNA level from week 4 to week 12 . eRVR was seen in $89 \%$ and $79 \%$ of patients in groups 1 and 2, respectively, and of these, $95 \%$ and $93 \%$ achieved SVR. In group 3, an eRVR was seen in $59 \%$ of patients, and of these, $47 \%$ went on to achieve SVR. AEs included alterations in liver-function tests, fatigue, nausea, headache, dizziness, insomnia, pruritus, rash, and vomiting. 
An additional open-label, phase 2a trial compared treatment with daclatasvir (an NS5A replication complex inhibitor) and asunaprevir (an NS3 PI) alone or in combination with PegIFN $\alpha-2 a$ and RBV for 24 weeks. ${ }^{119}$ Patients were prior null responders with HCV genotype 1 infection. Results showed $36 \%$ of patients in the IFN-free arm had SVRs after 12 and 24 weeks of treatment. Those majority of those that did not respond had viral breakthroughs and developed resistant mutations to daclatasvir and asunaprevir. Patients treated with combination therapy all had SVRs at 12 weeks after completion of therapy, and $9 / 10$ patients had SVR at 24 weeks. Diarrhea and elevation in alanine aminotransferase (ALT) were seen as complications.

Consistently promising results were seen in a similar open-label, phase 2a trial again evaluating 24 weeks of combination therapy with daclatasvir and asunaprevir in HCV genotype 1 null responders. ${ }^{120}$ All nine patients who completed therapy had undetectable viral loads as early as 8 weeks and achieved SVR at 12 and 24 weeks after treatment. There were no viral breakthroughs. Diarrhea was commonly seen, and two serious AEs were reported.

A large open-label, phase 2 a Japanese trial of 21 null responders and 22 patients intolerant to or medically ineligible for treatment with PegIFN/RBV showed encouraging results when treated with daclatasvir and asunaprevir. ${ }^{121} \mathrm{All}$ patients had HCV genotype $1 \mathrm{~b}$ infections. In the trial, $76.7 \%$ of patients achieved a SVR at 12 and 24 weeks after treatment $(90.5 \%$ of null responders and $63.6 \%$ of ineligible/ intolerant patients). Three intolerant/ineligible patients had viral breakthrough and four had post-treatment relapses. Seven patients did not complete the course of therapy, with reported AEs including diarrhea, nasopharyngitis, headache, elevations in AST, ALT, and hyperbilirubinemia.

BI 201335 (faldeprevir) and BI 207127 are potent and specific inhibitors of the HCVNS3/4A protease and the NS5B RNA-dependent RNA polymerase, respectively. An IFN-free combination of both anti-virals with RBV was recently evaluated $^{98}$ in a randomized open-label trial (SOUND-C2). Treatment-naive patients with HCV genotype 1 were treated over 4 weeks with 400 or 600 mg BI 207127 three times a day, BI $201335120 \mathrm{mg}$ once daily and RBV (1,000/1,200 mg daily in two doses). All patients had rapid and sharp declines in viral loads during the first 2 days, followed by a slower second-phase decline in all except 2 patients. One patient experienced a breakthrough (increase by $>1 \log _{10}$ from nadir during treatment) and one other experienced a $0.7 \log _{10}$ increase. Both were in the lower dose group, and were patients with genotype 1 a with high baseline viral loads. On day 29, all patients were switched per protocol to treatment with BI 201335 and PegIFN/RBV. At the higher dose level, there was no difference between genotypes $1 a$ and $1 b$, while patients with genotype $1 \mathrm{a}$ on $400 \mathrm{mg}$ three times daily had a lower response rate than those with genotype $1 \mathrm{~b}$. The PegIFN-sparing treatment was well tolerated. The most common AEs were mostly mild gastrointestinal effects, rashes, or photosensitivity. Laboratory parameters did not indicate any relevant changes from baseline, except for a continuous drop in ALT in all patients, a decrease in hemoglobin (median -1.7 and $-2.6 \mathrm{~g} / \mathrm{dL}$ ), and an increase in unconjugated bilirubin (median +9.8 and $+11.5 \mu \mathrm{mol} / \mathrm{L}$ ). IFN-sparing treatment with the NS3/4A inhibitor BI 201335, the NS5B inhibitor BI 207127, and RBV, demonstrated strong early antiviral activity against HCV genotype 1 with good safety and tolerability. ${ }^{98}$

\section{Resistance issues}

Resistance is characterized by rapid selection of viral variants bearing amino acid substitutions associated with an escape from the inhibitory antiviral effect of a drug. The emergence of mutations conferring cross-resistance to multiple therapies, along with a significantly diminishing number of treatment options is a main rationale for the development of direct-acting anti-viral agents (DAAs).

Because of the error-prone nature of RNA-dependent RNA polymerase of RNA viruses, drug resistance frequently emerges in patients treated with antiviral drugs and, therefore, limits the efficacy of these therapies. Resistance could become a major limitation in the treatment of patients with new HCV NS3-4A serine PIs. Resistance mutations against two HCV PI clinical candidates, BILN 2061 and VX-950 (telaprevir) were evaluated in an HCV subgenomic replicon system. The conformation of $\mathrm{Arg}^{155}$ in the two published crystal structures of the NS3 protease-inhibitor complex was found to be similar to that in the telaprevir-protease complex. In addition, this conformation of $\mathrm{Arg}^{155}$ conferred stabilization of telaprevir binding as it allowed the maximal number of van der Waals contacts between the $\operatorname{Arg}^{155}$ side-chain and the inhibitor. Therefore, telaprevir is not expected to be affected by the substitutions at Asp ${ }^{168}$, compared with BILN 2061. ${ }^{122}$ It should be noted that substitutions at $\mathrm{Asp}^{168}$ had been identified in a previous study as the mutations responsible for resistance to a less potent $\mathrm{HCV}$ PI, which had an half maximal inhibitory concentration ( $\mathrm{IC}_{50}$ ) of about $1 \mu \mathrm{mol} / \mathrm{L}$ in a replicon cell assay. ${ }^{123}$ Another BILN 2061-resistant mutation, namely substitution of $\mathrm{Arg}^{155}$ with Gln (R155Q), was identified in a separate in vitro study. The R155Q mutant was found to be moderately resistant to BILN 2061 (a 24-fold increase in replicon cell $\left.\mathrm{IC}_{50}\right){ }^{122}$ although it is not clear whether this mutation confers resistance to telaprevir or not.

It has been demonstrated both in cell culture and in patients that drug-resistant mutants can emerge quickly, even with the most potent inhibitors of viral protease or polymerase. ${ }^{22}$ This has been attributed to several factors: (i) HCV replicates at a high rate in patients, producing an estimated $10^{10-12}$ virions per day; (ii) the HCV RNA-dependent RNA polymerase lacks a proof-reading function, and has an error rate of about $10^{-4}$ mutations per genome per replication cycle. As a result, there is an extremely high degree of heterogeneity in the viral population (quasispecies) in each patient; (iii) virally targeted inhibitors typically bind to a defined pocket of a viral protein, typically a single mutation in the viral genome is usually sufficient to disrupt the binding of inhibitors leading to resistance. Theoretically, all the possible single, double, or even triple mutations are already pre-existing in patients with HCV. Therefore, it has been estimated that coadministration of at least three DAAs are required to completely suppress the emergence of resistance. Compounds with a relatively high resistance barrier such as cyclophilin inhibitors could provide the key advantage in an IFN-free regimen. This obstacle emphasizes the importance of using multiple agents that act by different mechanisms to inhibit HCV.

\section{Prospects for the future of HCV treatment}

An important step forward in HCV treatment was the development of HCV model systems providing insights into the biology of $\mathrm{HCV}$, and opportunities for identifying and pursuing methods that could lead to the discovery of novel 
antiviral therapies for HCV. Therapeutics in the pipeline include STAT-C, monoclonal and polyclonal antibodies, and other promising novel treatment strategies. In theory, these therapeutic options have the potential to be much more effective against the virus, and be associated with fewer and less serious side effects than the current treatment combinations. The goal for the future of HCV treatment is to design novel agents with low toxicity, improved pharmacokinetic profiles, high oral bioavailability, and extended elimination half-life, with the eventual possibility of IFN-free and RBVfree treatment regimens. Novel therapeutics should also have activity with other approved therapeutics, which will help minimize the emergence of drug resistance.

\section{Conclusions}

The development of anti-viral agents for the treatment of HCV is proceeding with remarkable rapidity. Both viral and hostspecific targets show promise, although drug resistance and side effects are potential limitations. It is likely that combinations of specific viral and host-targeted inhibitors will eventually replace the current standard therapy of care with hopefully highly effective, yet well-tolerated antiviral medications.

\section{Conflict of interest}

None

\section{Author contributions}

Updating text and creating tables (KLM), writing the manuscript (RS), literature searches (MVS), critical reviewing of the manuscript $(\mathrm{CHW})$, organization and editing of the manuscript (GYW).

\section{Acknowledgments}

The support of the Herman Lopata Chair in Hepatitis Research (to GYW) is gratefully acknowledged.

\section{References}

[1] Centers for Disease Control and Prevention. Evaluation of acute hepatitis C infection surveillance - United States, 2008. MMWR Morbidity and mortality weekly report. 2010;59:1407-1410.

[2] Kim WR. The burden of hepatitis C in the United States. Hepatology 2002; 36(Suppl 1):S30-S34.

[3] Lauer GM, Walker BD. Hepatitis C virus infection. N Engl J Med 2001;345: 41-52.

[4] Hoofnagle JH. Course and outcome of hepatitis C. Hepatology. 2002; 36(Suppl 1):S21-S29.

[5] Alter MJ. Epidemiology of hepatitis C virus infection. World J Gastroenterol $2007 ; 13: 2436-2441$.

[6] Simmonds P, Holmes EC, Cha TA, Chan SW, McOmish F, Irvine B, et al. Classification of hepatitis $C$ virus into six major genotypes and a series of subtypes by phylogenetic analysis of the NS-5 region. J Gen Virol 1993;74: 2391-2399.

[7] Stuyver L, Rossau R, Wyseur A, Duhamel M, Vanderborght B, Van Heuverswyn $\mathrm{H}$, et al. Typing of hepatitis $\mathrm{C}$ virus isolates and characterization of new subtypes using a line probe assay. J Gen Virol 1993;74:10931102.

[8] Koev G, Kati W. The emerging field of HCV drug resistance. Expert Opin Investig Drugs 2008;17:303-319.

[9] Dienstag JL, McHutchison JG. American Gastroenterological Association technical review on the management of hepatitis C. Gastroenterology $2006 ; 130: 231-264$.
[10] Ghany MG, Strader DB, Thomas DL, Seeff LB. Diagnosis, management and treatment of hepatitis C: an update. Hepatology 2009;49:13351374.

[11] Heathcote EJ, Shiffman ML, Cooksley WG, Dusheiko GM, Lee SS, Balart L, et al. Peginterferon alfa-2a in patients with chronic hepatitis $C$ and cirrhosis. N Engl J Med 2000;343:1673-1680.

[12] McGovern BH, Abu Dayyeh BK, Chung RT. Avoiding therapeutic pitfalls: the rational use of specifically targeted agents against hepatitis $\mathrm{C}$ infection. Hepatology 2008;48:1700-1712.

[13] Martinot-Peignoux M, Boyer N, Pouteau M, Castelnau C, Giuily N, Duchatelle $\mathrm{V}$, et al. Predictors of sustained response to alpha interferon therapy in chronic hepatitis C. J Hepatol 1998;29:214-223.

[14] Abdelghany S, Patel K, Pauli M. Telaprevir: A novel, protease inhibitor for the treatment of hepatitis C virus. Formulary 2011;46:205-209,214$216,225-226$.

[15] Hofmann WP, Zeuzem S. A new standard of care for the treatment of chronic HCV infection. Nat Rev Gastroenterol Hepatol 2011;8:257-264.

[16] Jensen DM. A new era of hepatitis C therapy begins. N Engl J Med 2011; 364:1272-1274.

[17] Chisari FV. Unscrambling hepatitis C virus-host interactions. Nature 2005 ; 436:930-932.

[18] Lohmann V, Korner F, Koch J, Herian U, Theilmann L, Bartenschlager R. Replication of subgenomic hepatitis $C$ virus RNAs in a hepatoma cell line. Science 1999;285:110-113.

[19] Wölk B, Sansonno D, Kräusslich HG, Dammacco F, Rice CM, Blum HE, et al. Subcellular localization, stability, and trans-cleavage competence of the hepatitis C virus NS3-NS4A complex expressed in tetracycline-regulated cell lines. J Virol 2000;74:2293-2304.

[20] Egger D, Wölk B, Gosert R, Bianchi L, Blum HE, Moradpour D, et al. Expression of hepatitis $C$ virus proteins induces distinct membrane alterations including a candidate viral replication complex. J Virol 2002; 76:5974-5984.

[21] Schinazi RF, Bassit L, Gavegnano C. HCV drug discovery aimed at viral eradication. J Viral Hepat 2010;17:77-90.

[22] Sarrazin C, Zeuzem S. Resistance to direct antiviral agents in patients with hepatitis C virus infection. Gastroenterology 2010;138:447-462.

[23] Raney KD, Sharma SD, Moustafa IM, Cameron CE. Hepatitis C virus nonstructural protein 3 (HCV NS3): a multifunctional antiviral target. J Biol Chem 2010;285:22725-22731.

[24] Schregel V, Jacobi S, Penin F, Tautz N. Hepatitis C virus NS2 is a protease stimulated by cofactor domains in NS3. Proc Natl Acad Sci U S A 2009;106: 5342-5347.

[25] Brass V, Berke JM, Montserret R, Blum HE, Penin F, Moradpour D. Structural determinants for membrane association and dynamic organization of the hepatitis C virus NS3-4A complex. Proc Natl Acad Sci U S A 2008;105: $14545-14550$.

[26] Lindenbach BD, Prágai BM, Montserret R, Beran RK, Pyle AM, Penin F, et al. The $C$ terminus of hepatitis $C$ virus NS4A encodes an electrostatic switch that regulates NS5A hyperphosphorylation and viral replication. J Virol 2007;81:8905-8918.

[27] Phan T, Kohlway A, Dimberu P, Pyle AM, Lindenbach BD. The acidic domain of hepatitis $C$ virus NS4A contributes to RNA replication and virus particle assembly. J Virol 2011;85:1193-1204.

[28] Ago H, Adachi T, Yoshida A, Yamamoto M, Habuka N, Yatsunami K, et al. Crystal structure of the RNA-dependent RNA polymerase of hepatitis C virus. Structure 1999;7:1417-1426.

[29] Bressanelli S, Tomei L, Roussel A, Incitti I, Vitale RL, Mathieu M, et al. Crystal structure of the RNA-dependent RNA polymerase of hepatitis C virus. Proc Natl Acad Sci U S A 1999;96:13034-13039.

[30] Lesburg CA, Cable MB, Ferrari E, Hong Z, Mannarino AF, Weber PC. Crystal structure of the RNA-dependent RNA polymerase from hepatitis $C$ virus reveals a fully encircled active site. Nat Struct Biol 1999;6:937-943.

[31] Tanji Y, Kaneko T, Satoh S, Shimotohno K. Phosphorylation of hepatitis C virus-encoded nonstructural protein NS5A. J Virol 1995;69:3980-3986.

[32] Ghosh A, Sarkar SN, Sen GC. Cell growth regulatory and antiviral effects of the P69 isozyme of 2-5 (A) synthetase. Virology $2000 ; 266: 319-328$.

[33] Majumder M, Ghosh AK, Steele R, Ray R, Ray RB. Hepatitis C virus NS5A physically associates with $\mathrm{p} 53$ and regulates $\mathrm{p} 21 /$ waf 1 gene expression in a p53-dependent manner. J Virol 2001;75:1401-1407.

[34] Abe T, Kaname $Y$, Hamamoto I, Tsuda Y, Wen X, Taguwa S, et al. Hepatitis C virus nonstructural protein $5 \mathrm{~A}$ modulates the toll-like receptor-MyD88dependent signaling pathway in macrophage cell lines. J Virol 2007;81: 8953-8966.

[35] Kanda T, Steele R, Ray R, Ray RB. Inhibition of intrahepatic gamma interferon production by hepatitis $C$ virus nonstructural protein $5 \mathrm{~A}$ in transgenic mice. J Virol 2009;83:8463-8469.

[36] Tamura R, Kanda T, Imazeki F, Wu S, Nakamoto S, Tanaka T, et al. Hepatitis C Virus nonstructural 5A protein inhibits lipopolysaccharide-mediated apoptosis of hepatocytes by decreasing expression of Toll-like receptor 4 . J Infect Dis 2011;204:793-801. 
[37] Lukavsky PJ. Structure and function of HCV IRES domains. Virus Res 2009; 139:166-171.

[38] Dutkiewicz M, Swiqtkowska A, Ciesiołka J. Structure and function of the non-coding regions of hepatitis C viral RNA. Postepy Biochem 2006;52:6271.

[39] Tsukiyama-Kohara K, Iizuka N, Kohara M, Nomoto A. Internal ribosome entry site within hepatitis C virus RNA. J Virol 1992;66:1476-1483.

[40] Pestova TV, Shatsky IN, Fletcher SP, Jackson RJ, Hellen CU. A prokaryoticlike mode of cytoplasmic eukaryotic ribosome binding to the initiation codon during internal translation initiation of hepatitis $C$ and classical swine fever virus RNAs. Genes Dev 1998;12:67-83.

[41] Kolupaeva VG, Pestova TV, Hellen CU. An enzymatic footprinting analysis of the interaction of $40 \mathrm{~S}$ ribosomal subunits with the internal ribosomal entry site of hepatitis C virus. J Virol 2000;74:6242-6250.

[42] Pisarev AV, Shirokikh NE, Hellen CU. Translation initiation by factorindependent binding of eukaryotic ribosomes to internal ribosomal entry sites. C R Biol 2005;328:589-605.

[43] Schwegmann A, Brombacher F. Host-directed drug targeting of factors hijacked by pathogens. Sci Signal 2008;1:re8.

[44] Tai AW, Chung RT. Treatment failure in hepatitis C: mechanisms of nonresponse. J Hepatol 2009;50:412-420.

[45] Brass AL, Dykxhoorn DM, Benita Y, Yan N, Engelman A, Xavier RJ, et al. Identification of host proteins required for HIV infection through a functional genomic screen. Science 2008;319:921-926.

[46] Ali N, Pruijn G], Kenan DJ, Keene JD, Siddiqui A. Human La antigen is required for the hepatitis $C$ virus internal ribosome entry site-mediated translation. J Biol Chem 2000;275:27531-27540.

[47] Ali N, Siddiqui A. The La antigen binds $5^{\prime}$ noncoding region of the hepatitis $C$ virus RNA in the context of the initiator AUG codon and stimulates internal ribosome entry site-mediated translation. Proc Natl Acad Sci U S A 1997; 94:2249-2254.

[48] Isoyama T, Kamoshita N, Yasui K, Iwai A, Shiroki K, Toyoda H, et al. Lower concentration of La protein required for internal ribosome entry on hepatitis C virus RNA than on poliovirus RNA. J Gen Virol 1999;80:2319-2327.

[49] Isken $O$, Baroth $M$, Grassmann CW, Weinlich S, Ostareck DH, OstareckLederer $\mathrm{A}$, et al. Nuclear factors are involved in hepatitis $\mathrm{C}$ virus RNA replication. RNA 2007;13:1675-1692.

[50] Gontarek RR, Gutshall LL, Herold KM, Tsai J, Sathe GM, Mao J, et al. hnRNP $\mathrm{C}$ and polypyrimidine tract-binding protein specifically interact with the pyrimidine-rich region within the $3^{\prime}$ NTR of the HCV RNA genome. Nucleic Acids Res 1999;27:1457-1463.

[51] Hahm B, Kim YK, Kim JH, Kim TY, Jang SK. Heterogeneous nuclear ribonucleoprotein $L$ interacts with the $3^{\prime}$ border of the internal ribosomal entry site of hepatitis C virus. J Virol 1998;72:8782-8788.

[52] Kim CS, Seol SK, Song OK, Park JH, Jang SK. An RNA-binding protein, hnRNP A1, and a scaffold protein, septin 6 , facilitate hepatitis $C$ virus replication. J Virol 2007;81:3852-3865.

[53] Zhang Z, Harris D, Pandey VN. The FUSE binding protein is a cellular factor required for efficient replication of hepatitis $C$ virus. J Virol 2008;82:57615773.

[54] Clerte C, Hall KB. The domains of polypyrimidine tract binding protein have distinct RNA structural preferences. Biochemistry 2009;48:2063-2074.

[55] Hara H, Aizaki H, Matsuda M, Shinkai-Ouchi F, Inoue $Y$, Murakami K, et al. Involvement of creatine kinase $B$ in hepatitis $C$ virus genome replication through interaction with the viral NS4A protein. J Virol 2009;83:51375147.

[56] Ali N, Siddiqui A. Interaction of polypyrimidine tract-binding protein with the $5^{\prime}$ noncoding region of the hepatitis $C$ virus RNA genome and its functional requirement in internal initiation of translation. J Virol 1995;69:63676375.

[57] Shirasaki T, Honda M, Mizuno H, Shimakami T, Okada H, Sakai $Y$, et al. La protein required for internal ribosome entry site-directed translation is a potential therapeutic target for hepatitis C virus replication. J Infect Dis 2010;202:75-85.

[58] Shimazaki T, Honda M, Kaneko S, Kobayashi K. Inhibition of internal ribosomal entry site-directed translation of $\mathrm{HCV}$ by recombinant IFN-alpha correlates with a reduced La protein. Hepatology 2002;35:199-208.

[59] Barth H, Schnober EK, Neumann-Haefelin C, Thumann C, Zeisel MB, Diepolder HM, et al. Scavenger receptor class B is required for hepatitis C virus uptake and cross-presentation by human dendritic cells. J Virol 2008; 82:3466-3479.

[60] Grove J, Huby T, Stamataki Z, Vanwolleghem T, Meuleman P, Farquhar M, et al. Scavenger receptor BI and BII expression levels modulate hepatitis C virus infectivity. J Virol 2007;81:3162-3169.

[61] McKeating JA, Zhang LQ, Logvinoff C, Flint M, Zhang J, Yu J, et al. Diverse hepatitis $\mathrm{C}$ virus glycoproteins mediate viral infection in a CD81-dependent manner. J Virol 2004;78:8496-8505.

[62] Meuleman P, Hesselgesser J, Paulson M, Vanwolleghem T, Desombere I, Reiser $\mathrm{H}$, et al. Anti-CD81 antibodies can prevent a hepatitis $\mathrm{C}$ virus infection in vivo. Hepatology $2008 ; 48: 1761-1768$.
[63] Lupberger J, Zeisel MB, Xiao F, Thumann C, Fofana I, Zona L, et al. EGFR and EphA2 are host factors for hepatitis $C$ virus entry and possible targets for antiviral therapy. Nat Med 2011;17:589-595.

[64] Broering TJ, Garrity KA, Boatright NK, Sloan SE, Sandor F, Thomas WD, et al. Identification and characterization of broadly neutralizing human monoclonal antibodies directed against the E2 envelope glycoprotein of hepatitis C virus. J Virol 2009;83:12473-12482.

[65] Burioni R, Perotti M, Mancini N, Clementi M. Perspectives for the utilization of neutralizing human monoclonal antibodies as anti-HCV drugs. J Hepatol 2008;49:299-300.

[66] Law M, Maruyama T, Lewis J, Giang E, Tarr AW, Stamataki Z, et al. Broadly neutralizing antibodies protect against hepatitis $C$ virus quasispecies challenge. Nat Med 2008;14:25-27.

[67] Meunier JC, Russell RS, Goossens V, Priem S, Walter H, Depla E, et al. Isolation and characterization of broadly neutralizing human monoclonal antibodies to the e1 glycoprotein of hepatitis C virus. J Virol 2008;82:966973.

[68] von Hahn T, Rice CM. Hepatitis C virus entry. J Biol Chem 2008;283:36893693.

[69] Barth H, Schnober EK, Zhang F, Linhardt RJ, Depla E, Boson B, et al. Viral and cellular determinants of the hepatitis $C$ virus envelope-heparan sulfate interaction. J Virol 2006;80:10579-10590.

[70] Pileri P, Uematsu Y, Campagnoli S, Galli G, Falugi F, Petracca R, et al. Binding of hepatitis C virus to CD81. Science $1998 ; 282$ :938-941.

[71] Scarselli E, Ansuini H, Cerino R, Roccasecca RM, Acali S, Filocamo G, et al. The human scavenger receptor class $B$ type I is a novel candidate receptor for the hepatitis C virus. EMBO J 2002;21:5017-5025.

[72] Evans MJ, von Hahn T, Tscherne DM, Syder AJ, Panis M, Wölk B, et al. Claudin-1 is a hepatitis $C$ virus co-receptor required for a late step in entry. Nature 2007;446:801-805.

[73] Ploss A, Evans MJ, Gaysinskaya VA, Panis M, You H, de Jong YP, et al. Human occludin is a hepatitis $C$ virus entry factor required for infection of mouse cells. Nature 2009;457:882-886.

[74] Wakita T, Pietschmann T, Kato T, Date T, Miyamoto M, Zhao Z, et al. Production of infectious hepatitis $C$ virus in tissue culture from a cloned viral genome. Nat Med 2005;11:791-796.

[75] Lindenbach BD, Evans MJ, Syder AJ, Wolk B, Tellinghuisen TL, Liu CC, et al. Complete replication of hepatitis C virus in cell culture. Science 2005;309: 623-626.

[76] Zhong J, Gastaminza P, Cheng G, Kapadia S, Kato T, Burton DR, et al. Robust hepatitis C virus infection in vitro. Proc Natl Acad Sci U S A 2005; 102:9294-9299.

[77] Gastaminza P, Whitten-Bauer C, Chisari FV. Unbiased probing of the entire hepatitis $C$ virus life cycle identifies clinical compounds that target multiple aspects of the infection. Proc Natl Acad Sci U S A 2010;107:291-296.

[78] Davis GL, Nelson DR, Terrault N, Pruett TL, Schiano TD, Fletcher CV, et al. A randomized, open-label study to evaluate the safety and pharmacokinetics of human hepatitis $\mathrm{C}$ immune globulin (Civacir) in liver transplant recipients. Liver Transpl 2005;11:941-949.

[79] Masson D, Koseki M, Ishibashi M, Larson CJ, Miller SG, King BD, et al. Increased HDL cholesterol and apoA-I in humans and mice treated with a novel SR-BI inhibitor. Arterioscler Thromb Vasc Biol 2009;29:2054-2060.

[80] Eren R, Landstein D, Terkieltaub D, Nussbaum O, Zauberman A, Ben-Porath $\mathrm{J}$, et al. Preclinical evaluation of two neutralizing human monoclonal antibodies against hepatitis $\mathrm{C}$ virus (HCV): a potential treatment to prevent HCV reinfection in liver transplant patients. J Virol 2006;80:2654-2664.

[81] Charlton M, Seaberg E, Wiesner R, Everhart J, Zetterman R, Lake J, et al. Predictors of patient and graft survival following liver transplantation for hepatitis C. Hepatology 1998;28:823-830.

[82] Rodriguez-Luna $H$, Vargas HE. Management of hepatitis $C$ virus infection in the setting of liver transplantation. Liver Transpl 2005;11:479-489.

[83] Samuel D. Antiviral treatment of recurrent hepatitis $C$ after liver transplantation: the need for a multifaceted approach. Hepatology 2005;41:436438.

[84] Everson GT. Treatment of hepatitis $C$ in the patient with decompensated cirrhosis. Clin Gastroenterol Hepatol 2005;3(Suppl 2):S106-S112.

[85] Farci P, Alter HJ, Wong DC, Miller RH, Govindarajan S, Engle R, et al. Prevention of hepatitis $C$ virus infection in chimpanzees after antibodymediated in vitro neutralization. Proc Natl Acad Sci U S A 1994;91:77927796.

[86] Farci P, Shimoda A, Wong D, Cabezon T, De Gioannis D, Strazzera A, et al. Prevention of hepatitis $C$ virus infection in chimpanzees by hyperimmune serum against the hypervariable region 1 of the envelope 2 protein. Proc Natl Acad Sci U S A 1996;93:15394-15399.

[87] Schiano TD, Charlton M, Younossi Z, Galun E, Pruett T, Tur-Kaspa R, et al. Monoclonal antibody HCV-AbXTL68 in patients undergoing liver transplantation for HCV: results of a phase 2 randomized study. Liver Transpl 2006; 12:1381-1389. 
[88] Hézode C, Forestier N, Dusheiko G, Ferenci P, Pol S, Goeser T, et al. Telaprevir and peginterferon with or without ribavirin for chronic $\mathrm{HCV}$ infection. N Engl J Med 2009;360:1839-1850.

[89] McHutchison JG, Everson GT, Gordon SC, Jacobson IM, Sulkowski M, Kauffman $\mathrm{R}$, et al. Telaprevir with peginterferon and ribavirin for chronic HCV genotype 1 infection. N Engl J Med 2009;360:1827-1838.

[90] Sarrazin C, Rouzier R, Wagner F, Forestier N, Larrey D, Gupta SK, et al. SCH 503034, a novel hepatitis C virus protease inhibitor, plus pegylated interferon alpha-2b for genotype 1 nonresponders. Gastroenterology 2007; 132:1270-1278

[91] McHutchison JG, Manns MP, Muir AJ, Terrault NA, Jacobson IM, Afdhal NH, et al. Telaprevir for previously treated chronic HCV infection. N Engl J Med 2010;362:1292-1303.

[92] Poordad F, McCone J Jr, Bacon BR, Bruno S, Manns MP, Sulkowski MS, et al. Boceprevir for untreated chronic HCV genotype 1 infection. N Engl J Med 2011;364:1195-1206.

[93] Venkatraman S, Bogen SL, Arasappan A, Bennett F, Chen K, Jao E, et al. Discovery of (1R,5S)-N-[3-amino-1-(cyclobutylmethyl)-2,3-dioxopropyl]3-[2(S)-[[[(1,1-dimethylethyl)amino]carbonyl]amino]-3,3-dimethyl-1oxobutyl]- 6,6-dimethyl-3-azabicyclo[3.1.0] hexan-2(S)-carboxamide ( $\mathrm{SCH}$ 503034), a selective, potent, orally bioavailable hepatitis $\mathrm{C}$ virus NS3 protease inhibitor: a potential therapeutic agent for the treatment of hepatitis C infection. J Med Chem 2006;49:6074-6086.

[94] Ciesek S, von Hahn T, Manns MP. Second-wave protease inhibitors: choosing an heir. Clin Liver Dis 2011;15:597-609.

[95] Raboisson $\mathrm{P}$, Lin TI, Kock $\mathrm{H}$, Vendeville $\mathrm{S}$, Vreken WV, McGowan $\mathrm{D}$, et al. Discovery of novel potent and selective dipeptide hepatitis C virus NS3/4A serine protease inhibitors. Bioorg Med Chem Lett 2008;18:5095-5100.

[96] Reesink HW, Fanning GC, Farha KA, Weegink C, Van Vliet A, Van 't Klooster G, et al. Rapid HCV-RNA decline with once daily TMC435: a phase I study in healthy volunteers and hepatitis C patients. Gastroenterology 2010;138: 913-921.

[97] White PW, Llinas-Brunet M, Amad M, Bethell RC, Bolger G, Cordingley MG, et al. Preclinical Characterization of BI 201335, a C-Terminal Carboxylic Acid Inhibitor of the Hepatitis C Virus NS3-NS4A Protease. Antimicrob Agents Chemother 2010;54:4611-4618.

[98] Zeuzem S, Asselah T, Angus PW, Zarski J-PH, Larrey D, Mullhaupt B, et al. Strong antiviral activity and safety of IFN-sparing treatment with the protease inhibitor BI 201335, the HCV polymerase inhibitor BI 207127 and ribavirin in patients with chronic Hepatitis C. Hepatology 2010;52(Suppl): 876A-877A.

[99] Paulson MS, Yang H, Shih IH, Feng JY, Mabery EM, Robinson MF, et al. Comparison of HCV NS3 protease and NS5B polymerase inhibitor activity in $1 \mathrm{a}, 1 \mathrm{~b}$ and $2 \mathrm{a}$ replicons and $2 \mathrm{a}$ infectious virus. Antiviral Res 2009;83: 135-142.

[100] Smolic R, Smolic M, Andorfer JH, Wu CH, Smith RM, Wu GY. Inhibition of hepatitis $\mathrm{C}$ virus replication by single-stranded RNA structural mimics. World J Gastroenterol 2010;16:2100-2108.

[101] Lemm JA, O'Boyle D, Liu M, Nower PT, Colonno R, Deshpande MS, et al. Identification of hepatitis C virus NS5A inhibitors. J Virol 2010;84:482-491.

[102] Einav S, Sklan EH, Moon HM, Gehrig E, Liu P, Hao Y, et al. The nucleotide binding motif of hepatitis $\mathrm{C}$ virus NS4B can mediate cellular transformation and tumor formation without Ha-ras co-transfection. Hepatology 2008;47: 827-835.

[103] Ikeda M, Abe K, Yamada M, Dansako H, Naka K, Kato N. Different anti-HCV profiles of statins and their potential for combination therapy with interferon. Hepatology 2006;44:117-125.

[104] Coelmont L, Kaptein S, Paeshuyse J, Vliegen I, Dumont JM, Vuagniaux G, et al. Debio 025, a cyclophilin binding molecule, is highly efficient in clearing hepatitis C virus (HCV) replicon-containing cells when used alone or in combination with specifically targeted antiviral therapy for HCV (STAT-C) inhibitors. Antimicrob Agents Chemother 2009;53:967-976.

[105] Flisiak R, Feinman SV, Jablkowski M, Horban A, Kryczka W, Pawlowska M, et al. The cyclophilin inhibitor Debio 025 combined with PEG IFNalpha2a significantly reduces viral load in treatment-naïve hepatitis $C$ patients. Hepatology 2009;49:1460-1468.

[106] Paeshuyse J, Kaul A, De Clercq E, Rosenwirth B, Dumont JM, Scalfaro P, et al. The non-immunosuppressive cyclosporin DEBIO-025 is a potent inhibitor of hepatitis C virus replication in vitro. Hepatology $2006 ; 43: 761$ 770.

[107] Jopling CL, Yi M, Lancaster AM, Lemon SM, Sarnow P. Modulation of hepatitis C virus RNA abundance by a liver-specific MicroRNA. Science 2005;309:1577-1581.

[108] Lanford RE, Hildebrandt-Eriksen ES, Petri A, Persson R, Lindow M, Munk ME, et al. Therapeutic silencing of microRNA-122 in primates with chronic hepatitis $C$ virus infection. Science 2010;327:198-201.

[109] Qiu D, Lemm JA, O'Boyle DR, Sun JH, Nower PT, Nguyen V, et al. HCV NS5A Inhibitors Modulate Multiple Aspects of NS5A Expression. J Gen Virol 2011; 87:2320-2329.

[110] Fridell RA, Qiu D, Wang C, Valera L, Gao M. Resistance analysis of the hepatitis C virus NS5A inhibitor BMS-790052 in an in vitro replicon system. Antimicrob Agents Chemother 2010;54:3641-3650.

[111] Nettles RE, Gao M, Bifano M, Chung E, Persson A, Marbury TC, et al. Multiple ascending dose study of BMS-790052, a nonstructural protein 5A replication complex inhibitor, in patients infected with hepatitis $C$ virus genotype 1 . Hepatology 2011;54:1956-1965.

[112] Rodriguez-Torres M, Lawitz E, Kowdley KV, Nelson DR, Dejesus E, McHutchinson JG, et al. Sofosbuvir (GS-7977) plus peginterferon/ribavirin in treatment-naïvepatients with HCV genotype 1: A randomized 28-day, dose ranging trial. J Hepatol 2013;58:663-668.

[113] Forestier N, Larrey D, Marcellin P, Benhamou Y, Guyader D, Bradford W, et al. Antiviral activity and safety of ITMN-191 in combination with peginterferon alfa-2a and ribavirin in patients with chronic hepatitis $\mathrm{C}$ virus (HCV). J Hepatol 2009;50(Suppl 2):S35.

[114] Gane E, Roberts S, Stedman C, Angus P, Ritchie B, Elston R, et al. Early on treatment responses during pegylated interferon plus ribavirin are increased following 13 days of combination nucleoside polymerase (RG7128) and protease (RG7227) inhibitor therapy (INFORM-1). J Hepatol 2010;52(Suppl):S291-S292.

[115] Seiwert SD, Andrews SW, Jiang Y, Serebryany V, Tan H, Kossen $K$, et al. Preclinical Characteristics of the Hepatitis C Virus NS3/4A Protease Inhibito ITMN-191 (R7227). Antimicrob Agents Chemother 2008;52:4432-4441.

[116] Le Pogam S, Seshaadri A, Ewing A, Kang H, Kosaka A, Yan JM, et al. RG7128 Alone or in Combination with Pegylated Interferon-alpha 2a and Ribavirin Prevents Hepatitis C Virus (HCV) Replication and Selection of Resistant Variants in HCV-Infected Patients. J Infect Dis 2010;202:1510-1519.

[117] Lam AM, Murakami E, Espiritu C, Steuer HM, Niu C, Keilman M, et al. PSI7851 , a pronucleotide of beta-D-2'-deoxy-2'-fluoro-2'-C-methyluridine monophosphate, is a potent and pan-genotype inhibitor of hepatitis $C$ virus replication. Antimicrob Agents Chemother 2010;54:3187-3196.

[118] Poordad F, Lawitz E, Kowdley KV, Cohen DE, Podsadecki T, Siggelkow S, et al. Exploratory study of oral combination antiviral therapy for hepatitis $\mathrm{C}$. NEJM 2013;368:45-53.

[119] Lok AS, Gardiner DF, Lawitz E, Mortorell C, Everson GT, Ghalib R, et al. Preliminary study of two antiviral agents for hepatitis c genotype 1 . N Engl J Med 2012;366:216-224.

[120] Chayama K, Takahashi S, Toyota J, Karino Y, Ikeda K, Ishikawa H, et al. Hepatology 2012;5:742-748.

[121] Suzuki $Y$, Ikeda $K$, Suzuki F, Toyota J, Karino $Y$, Chayama $K$. Dual ora therapy with daclatasvir and asunaprevir for patients with HCV genotype $1 \mathrm{~b}$ infection and limited treatment options. J Hepatol 2013;58:655-662.

[122] Lin C, Lin K, Luong YP, Rao BG, Wei YY, Brennan DL, et al. In vitro resistance studies of hepatitis C virus serine protease inhibitors, VX-950 and BILN 2061 - Structural analysis indicates different resistance mechanisms. J Bio Chem 2004;279:17508-17514.

[123] Trozzi C, Bartholomew L, Ceccacci A, Biasiol G, Pacini L, Altamura S, et al. In vitro selection and characterization of hepatitis $C$ virus serine protease variants resistant to an active-site peptide inhibitor. J Virol 2003;77:36693679 . 